\title{
Distribution patterns and floristic analysis of the Colymbada tauromenitana (Guss.) Holub populations in Sicily (Italy)
}

\author{
SaVerio Sciandrello*, Sonia D'agostino \\ Department of Biological, Geological and Environmental Sciences, \\ University of Catania, Via A. Longo 19, I - 95125 Catania, Italy
}

\begin{abstract}
Colymbada tauromenitana (Guss.) Holub (Asteraceae) is a rare paleoendemic, chasmophyte species, occurring on calcareous cliffs in the eastern part of Sicily (Italy). The aim of this work is to analyze the structure and floristic composition of the C. tauromenitana community, in order to characterize the diversity of populations in relation to different ecological data. In all, 61 plots were examined. For each plot, the floristic composition and the cover of the species were determined using the standard relevé method. Three vegetation types emerged from canonical components analysis (CCA), correlated to a gradient of environmental conditions ranging from the coast to inland areas. The first group with Lomelosia cretica and Dianthus rupicola subsp. rupicola was correlated to thermo-xerophilous conditions (lower thermo-Mediterranean belt), the second group with Silene fruticosa and Colymbada tauromenitana was linked to thermophilous conditions (upper thermo-Mediterranean belt) and the third with Dianthus siculus and Odontites bocconei was correlated to mesophilous conditions (meso-Mediterranean belt). Altitude is the main factor influencing both species richness and floristic composition. The density of $C$. tauromenitana is influenced mainly by rainfall. Finally, we propose a new risk status for this rare species.
\end{abstract}

Keywords: Colymbada tauromenitana, conservation status, distribution, ecology, Italy, paleoendemic, plant diversity, Sicily

\section{Introduction}

The high level of plant endemism in the Mediterranean area is related to the environmental heterogeneity, particular climatic conditions, geological and paleogeographic factors as well as millennial human land use (Cowling et al. 1996, Médail and Verlaque 1997, CARmel and Flather 2004, Minissale and Sciandrello 2013).

* Corresponding author, e-mail: s.sciandrello@unict.it 
Plant conservation strategies are a crucial issue in the Mediterranean area, due to excessive human impact on the natural landscape which in several cases has led to the loss of habitats and endemic species (Schröter et al. 2005, PisAnu et al. 2011, Tomaselli et al. 2012). Sicily is one of the most important centers of plant diversity in the Mediterranean region (MÉDAIL and QuÉZEL 1999). With about 3,300 vascular taxa (species and subspecies) according to GIARDINA et al. (2007), it accounts for nearly $43 \%$ of the entire vascular flora of Italy (7,634 species, according to CONTI et al. 2005). The importance of the vascular flora of Sicily lies not only in the total number of taxa but also in the considerable number of endemic species (about 13\% according to BRULLo et al. 2011). Chasmophytes represent one of the most important groups of plants within the flora of Sicily (DAVIS 1951, THOMPSON 2005). This ecological group includes one very interesting taxon, Colymbada tauromenitana (Guss.) Holub (= Centaurea tauromenitana Guss.), a huge plant which grows on the limestone cliffs of the Peloritani district (Pirola 1961, Gramuglio et al. 1985, Brullo et al. 1995). This species is a paleoendemic species exclusive to eastern Sicily (ArenA et al. 1975). Currently, populations of $C$. tauromenitana are threatened by human activities, mainly represented by excavations for building, and by invasive plants, especially the expansion of Opuntia ficus-indica. The aim of this study is the analysis of the structure and floristic composition of the $C$. tauromenitana community, in order to characterize the diversity of populations in relation to different environmental conditions. These results will be useful for a proper evaluation of its conservation status and for the improvement of actions aimed at the conservation of this rare taxon.

\section{Materials and methods}

\section{Study area}

The study area includes the Peloritani district, in the eastern part of Sicily (Fig. 1). This area is characterized by mountains of moderate altitude, comprising, from south to north, Monte Tauro (245 m), Monte Petraro (475 m), Castelmola (496 m), Roccella (602 m), Monte Ziretto (381 m), Costa Ogliastro (466 m), Monte Veneretta (884 m), Monte Lapa (771m), Monte Castelluccio (501 m), Monte Pernice (712 m) and Monte Galfa (1,000 m). From a geological viewpoint the study area belongs to the Longi-Taormina and Capo S. Andrea unit. The lower subunit is formed by an epimetamorphic basement capped by Mesozoic-Cenozoic sedimentary cover made up, from bottom to top, of continental redbeds evolving upwards to platform carbonates (Lentini et al. 2000). All Colymbada tauromenitana populations are protected by Natura 2000 areas (EuropeAn COMMUNITY 1992) with the exception of the M. Petraro site.

Annual precipitation at the sites ranges from 600 to $1,000 \mathrm{~mm}$ and mean annual temperature varies between $19-20{ }^{\circ} \mathrm{C}$ (along the coast) and $13-14{ }^{\circ} \mathrm{C}$ (inner area) (Brullo et al. 1996).

According to the bioclimatic classification proposed by Rivas-MarTínEz (1993, 2004), the area under study is referred to the Mediterranean pluviseasonal oceanic bioclimate, with thermotypes ranging from the thermo-Mediterranean to the meso-Mediterranean and ombrotypes from the semiarid to lower humid. 


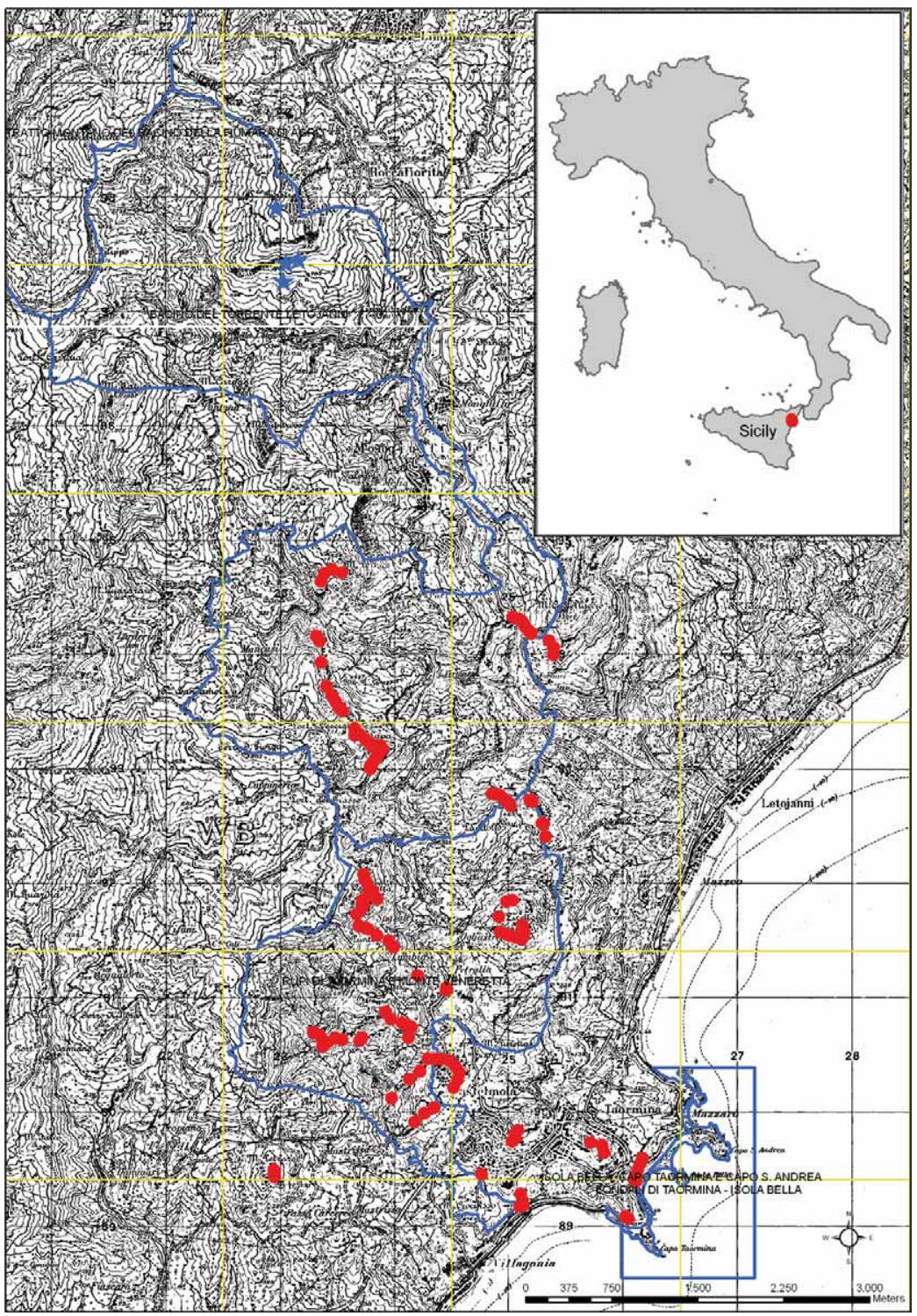

Fig. 1. Study area; red dots show the distribution area of Erucastretum virgati centauretosum tauromenitanae; blue stars indicate the distribution area of Erucastretum virgati dianthetosum sicu$l i$; blue line indicates Natura 2000 areas; yellow grid of $2 \times 2 \mathrm{~km}$ to assess area of occupancy.

\section{Data analysis}

The published data on the distribution of this species (Gussone 1827, LoJACONO 1908, Pirola 1961, Gramuglio 1967, Gramuglio et al. 1985) were reviewed and specimens of herbaria from Catania and Palermo were also examined. On the basis of these starting data, all the sites of Sicily in which C. tauromenitana has been reported were visited; in addition, 
other potentially suitable sites for the species were investigated. Our assessment of the Sicilian population size was based on a census in those sites where we found the species. The assignation of $C$. tauromenitana to an IUCN (International Union for Conservation of Nature) risk category (IUCN, 2001), was largely made on a quantitative assessment. The threats to $C$. tauromenitana in each locality were determined from the field observations. A grid of $2 \times 2 \mathrm{~km}$ was used to assess area of occupancy (AOO, defined as the area within the extent of occurrence, following IUCN (2008) and Rossi and GENTILI (2008). Conservation status was assessed following IUCN (2008) and the conservation measures adopted or proposed for the species were based on our field observations.

The field work, carried out in order to analyze the structure and composition of the $C$. tauromenitana plant community, was done in 2009-2012 during which 61 plots $(10 \times 10 \mathrm{~m})$ were made using the standard method of relevés (WESTHOFF and VAN DER MAAREL 1978). Numerical analysis (Cluster Analysis - WPGMA method, Chord coefficient) of relevé was performed using the software package SYN-TAX 2000 (PoDANI 2001). Environmental gradients and plant communities were examined with canonical component analysis (CCA), using the PC-ORD, v6, software. In particular, the CCA takes into account different quantitative data such as the distance from the sea (DS), altitude (Altit.), slope of terrain, number of species (N. sp.) and rock type. The original Braun-Blanquet sampling scale (BrAUNBLANQUET 1964) has been transformed into an ordinal scale, according to VAN DER MAAREL (1979). For the nomenclature of the species, GiARdina et al. (2007), RAIMONDO and SPADARO (2009) were followed, while phytosociological nomenclature follows BRULLo et al. (2002).

For each taxon, life form and chorological element are reported. The life form follows the Raunkiaer system as proposed by PignATti (1982), while for chorological elements BRullo et al. (1998a) are followed. The exsiccata (preserved in Botanical Museum of Catania) were studied with the help of Flora Europaea (Tutin et al. 1964-80), the Italian floras (Fiori 1923-29, Pignatti 1982).

Two indexes were chosen to estimate diversity: (1) species richness (SR), i.e., the total number of plant species recorded in a sample plot, and (2) Shannon-Wiener's diversity index $\left(H^{\prime}\right)$. This index takes into account the degree of equitability $(\mathrm{J})$ of the species distribution. SR and H' represent the $\alpha$-diversity level of the vegetation in relation to the size of the relevé. Spearman rank correlation coefficients were used to evaluate the importance of environmental factors in the distribution of the plant diversity. A p-value of $<0.05$ was taken as indicating a statistically significant difference or correlation.

The rock type classification follows LENTINI et al. (2000), which for this area recognizes four types: type 1 - Limestone and dolomite: detritic limestones with rudite clasts of quartz at the base (UT); type 2 - Limestone and dolomite: detritic limestones, biocalcarenites with brachiopods gray and reddish veined (UG); type 3 - Limestone and marl alternation in »Medolo facies« (UTm) and type 4 - »Flysch of Capo d'Orlando« (OMc).

\section{The study of the species and its habitat}

C. tauromenitana is a perennial herb or dwarf shrub, with erect stems, 50-100 (120) cm high, branched above. The species is diploid $(2 n=2 \times=20)$ (DE SANTIS et al. 1976) and flowers from the second half of May through the first half of July. Dissemination occurs between late July and early August. C. tauromenitana does not reproduce vegetatively (pers. observation). The current conservation status of C. tauromenitana in Sicily (CoNTI el al. 1997) is 
»low risk « (LR). According to our data, single individuals of C. tauromenitana can survive for several decades.

C. tauromenitana grows on limestone cliffs of the Peloritani district (Sicily) with other endemic species (ARENA et al. 1975, Sciandrello et al. 2013a), as Erucastrum virgatum (J. et C. Presl) C. Presl, Dianthus rupicola Biv. subsp. rupicola, Brassica incana Ten., Brassica raimondoi Sciandr., C. Brullo, Brullo, Giusso, Miniss. et Salmeri, Anthyllis vulneraria L. subsp. busambarensis (Lojac.) Pignatti, Antirrhinum siculum Mill., Dianthus siculus C. Presl in J. et C. Presl, Galium aetnicum Biv., Micromeria graeca (L.) Benth. ex Rchb. subsp. consentina (Ten.) Guinea, etc.; it is a member of the highly specialized rupicolous communities of the association Erucastretum virgati Brullo et Marcenò 1979 centauretosum tauromenitanae Pirola ex Brullo et Marcenò 1979 (Asplenietea trichomanis (Br.-Bl. in Meier et Br.-Bl. 1934) Oberd. 1977, Dianthion rupicolae Brullo et Marcenò 1979). The vegetation pattern of the area is characterized by perennial dry grasslands dominated mostly by caespitose hemicryptophytes, by rupicolous vegetation, rarely shrubby elements that are adapted to different habitats and restricted woods (SCIANDRELLO et al. 2013b).

\section{Results}

\section{Distribution and population size}

Our investigations confirmed 8 sites with Colymbada tauromenitana (Fig. 1): Monte Petraro (Castelmola); Villagonia, Isola Bella and Monte Tauro (Taormina); Castelmola and Roccella (Castelmola); Monte Veneretta (Castelmola); Monte Ziretto and Costa Ogliastro (Castelmola); Monte Lapa (Mongiuffi-Melia); Monte Pernice (Mongiuffi-Melia); Monte Castellaccio (Letojanni, Gallodoro, Mongiuffi Melia). The locality of Capo S. Alessio (GIARDINA et al. 2007) is not confirmed, while the M. Galfa site, characterized by potentially suitable cliffs for the growth of $C$. tauromenitana, has been carefully explored and the species has not been found. The areas in which the species occur vary between altitudes of 20-800 $\mathrm{m}$, on slopes of $40-90^{\circ}$ exposed mainly east, and a distance from the coastline that varies between 30 and $6,000 \mathrm{~m}$. The entire population of $C$. tauromenitana consisted of fewer than 7,200 plants, distributed with variable density (Tab. 1). The current populations of C. tauromenitana occupy (AOO) about $28 \mathrm{~km}^{2}$ (Fig. 1), distributed along the cliffs with the exception of the populations of M. Petraro and M. Castellaccio. The highest density is distributed on the cliffs facing east between M. Veneretta and M. Lapa with about 2,500 individuals (Fig. 2). Other interesting populations with high values of individuals were found in the area of Castelmola, on the cliffs facing east of M. Ziretto-Costa Ogliastro and on the south facing rocks of the Castello di Taormina, while low values were found along the coast, to M. Pernice and M. Petraro. Overall, the narrow distribution area of C. tauromenitana is linked to the substrate type (mainly limestone), with the exception of a small population of a few individuals, growing on conglomerate substrates to M. Petraro. We may therefore consider $C$. tauromenitana a narrow endemic of the carbonatic district of Taormina.

Finally, considering the number of individuals, the narrow area and several threats (invasive species, fire, natural collapses and stone extraction), we may conclude that the distribution area of $C$. tauromenitana is highly localized and at risk of further reduction. Therefore, based on the field investigation carried out in the present survey, we propose a new IUCN category, Vulnerable (VU A2ce, B1ab (ii,iii,iv)). 
Tab. 1. Sites where Colymbada tauromenitana has been located. No. plots - number of plots; No. ind. - number of individuals of C. tauromenitana; No. endemic - number of endemic plants; Rock type: UT - Limestone and dolomite with rudite clasts of quartz at the base, UG - Limestone and dolomite with brachiopods gray and reddish veined, UTm - Limestone and marl alternation, OMc - Flysch; No. species, number of species; T med mean temperature; Rainfall ( $\mathrm{mm}$ ) - annual precipitation.

\begin{tabular}{|c|c|c|c|c|c|c|c|c|c|c|c|}
\hline Locality & $\begin{array}{l}\frac{n}{0} \\
\frac{0}{2} \\
\dot{0}\end{array}$ & $\begin{array}{l}\dot{\vec{g}} \\
\dot{\dot{z}}\end{array}$ & 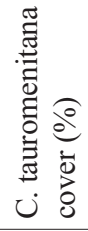 & 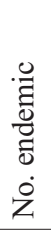 & 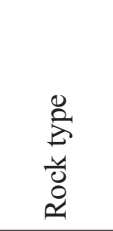 & 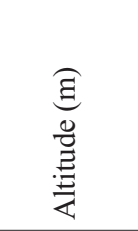 & 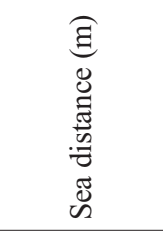 & 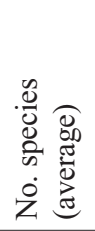 & 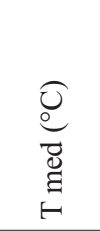 & 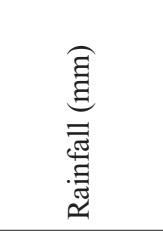 & 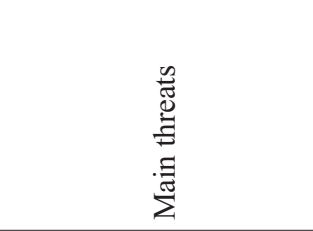 \\
\hline Monte Petraro (Castelmola) & 3 & 80 & 26 & 5 & OMc & 460 & 2210 & 21 & $16-17$ & $700-800$ & natural collapses, fire \\
\hline Villagonia (Taormina) & 3 & 280 & 16 & 7 & UT & $25-35$ & $95-130$ & 19 & $18-19$ & $600-700$ & invasive plants \\
\hline Rupi di Capotaormina & 1 & 30 & 5 & 5 & UT & 60 & 90 & 19 & $19-20$ & $600-700$ & invasive plants \\
\hline Monte Tauro e Castello di Taormina & 3 & 750 & 30 & 6 & UT & 350 & 600 & 19 & $17-18$ & $700-800$ & building, invasive plants \\
\hline Rupi di Castelmola & 5 & 1000 & 30 & 7 & UT & 480 & 1600 & 24 & $16-17$ & $800-900$ & invasive plants \\
\hline Rupi antistanti Castelmola & 3 & 600 & 26 & 6 & UT & 530 & 1850 & 24 & $16-17$ & $800-900$ & fire and pasture \\
\hline Roccella (Castelmola) & 2 & 100 & 25 & 5 & UT & 420 & 1680 & 22 & $16-17$ & $800-900$ & invasive plants \\
\hline Monte Lapa (Mongiuìffi Melia) & 4 & 1200 & 32 & 6 & UT & $620-650$ & $3000-3100$ & 28 & $14-15$ & $900-1000$ & fire, pasture \\
\hline Monte Pernice (Mongiuiffi Melia) & 4 & 250 & 20 & 8 & UTm & $500-530$ & 4200 & 15 & $15-16$ & $800-900$ & stone extraction \\
\hline $\begin{array}{l}\text { Monte Castellaccio (Letojanni, } \\
\text { Gallodoro, Mongiuffi Melia) }\end{array}$ & 3 & 350 & 26 & 5 & UT & 250 & 2500 & 21 & $17-18$ & $700-800$ & natural collapses \\
\hline $\begin{array}{l}\text { Monte Galfa (Roccafiorita, Mongiuffi } \\
\text { Melia) }\end{array}$ & 5 & 0 & 0 & 7 & UT-UG & $720-920$ & $6300-6700$ & 21 & $13-14$ & $1000-1200$ & fire, pasture \\
\hline
\end{tabular}



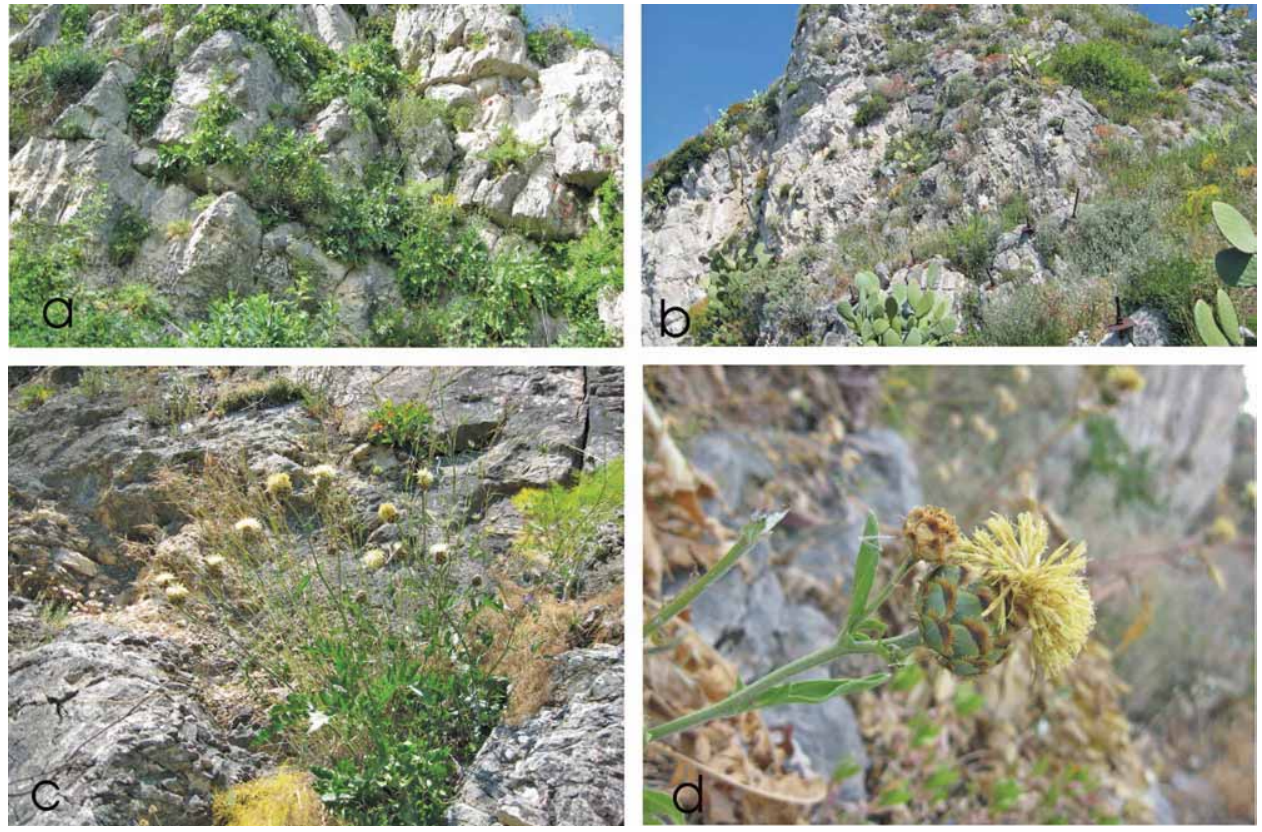

Fig. 2. Rupicolous vegetation with Colymbada tauromenitana on limestones outcrops of M. Veneretta (Castelmola) (a); Colymbada tauromenitana with the presence of Opuntia ficus-indica on cliffs of Taormina (b); plant in its peak flowering time (c, d).

\section{Plant communities and species diversity}

In total, 72 species of vascular plants have been recorded on the cliffs of the study area. Most species belong to Mediterranean elements, with the dominant life forms being chamaephytes (35\%) and hemicryptophytes (33\%), while the therophytes show low values $(3 \%)$.

The ecological features of the rupicolous plant community may be highlighted by the floristic composition and its variations along a gradient of conditions from the coast to the inland. The results of the cluster analysis (Fig. 3) show two main vegetation groups, each with specific indicator species. Group A (56 relevés) represents the coastal plant communities with Colymbada tauromenitana, while group B (5 relevés) represents inland plant communities without $C$. tauromenitana. Within group A, two sub-groups were distinguished: A1, comprising the thermo-mesophilous plant communities, and A2, which includes the thermo-xerophilous plant communities. Within sub-group A1 we can distinguish the rupicolous vegetation of the conglomeratic outcrops (A11) and plant communities of the limestone outcrops (A12), while the sub-group A2 includes the strictly coastal plant communities with sub-halophilous species (A21) and the thermophilous plant communities linked to marine ecological conditions (A22).

The species richness and Shannon-Wiener diversity index indicate that the plant communities near the coast show a moderate diversity with an average SR of 21.7 and an average Shannon-Wiener diversity index of $2.3(\mathrm{~J}=0.73)$. Both values increase by altitude in 
A

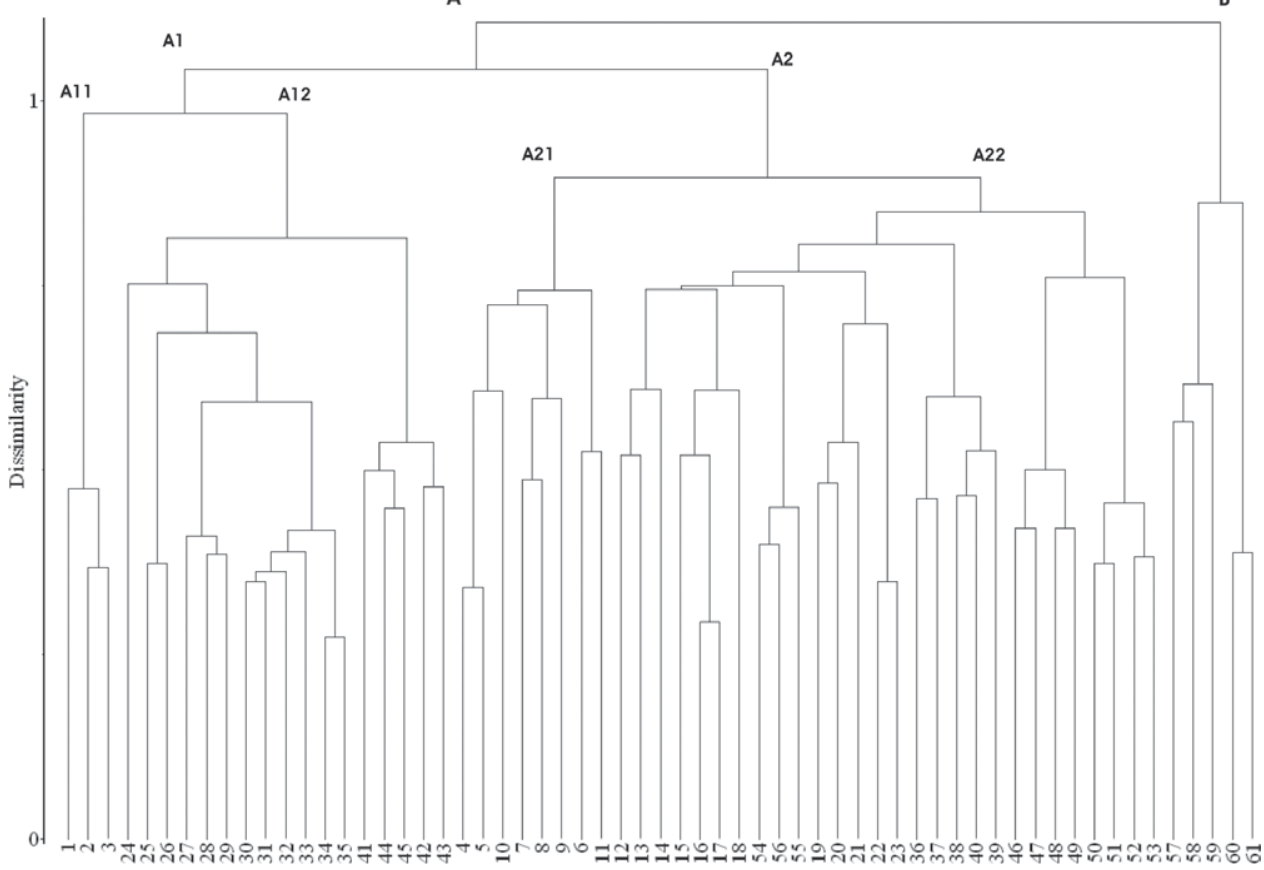

Fig. 3. Dendrogram resulting from cluster analysis of the plots (WPGMA method, Chord coefficient). Plant communities: A1 - Erucastretum virgati centauretosum tauromenitanae facies with Silene fruticosa; A2 - Erucastretum virgati centauretosum tauromenitanae facies with Lomelosia cretica; B - Erucastretum virgati dianthetosum siculi. 1-61 indicates the plots (relevés).

middle zones with an average of 24 species and a Shannon-Wiener diversity index of 2.5 (J $=0.79$ ). The highest areas (M. Galfa) have a moderate SR of 21 and Shannon-Wiener diversity index of $2.6(\mathrm{~J}=0.84)$ (Tab. 2).

Tab. 2. Relationship between species richness, standard deviation, equitability, Shannon-Wiener's diversity index and bioclimate zones. 1 - Monte Petraro; 2 - Villagonia, Capotaormina, Isola Bella, M. Tauro and Castello (Taormina); 3 - Roccella and Castelmola; 4 - M. Veneretta; 5 M. Ziretto and Costa Ogliastro; 6-M. Lapa; 7 - M. Pernice; 8 - M. Castellaccio; 9 - M. Galfa.

\begin{tabular}{|c|c|c|c|}
\hline & $\begin{array}{c}36 \text { plots }(2,3,5,6,7,8) \\
\text { thermomediterranean } \\
\text { lower zone }\end{array}$ & $\begin{array}{c}20 \text { plots }(1,4,5) \\
\text { thermomediterranean } \\
\text { upper zone }\end{array}$ & $\begin{array}{c}\mathbf{5} \text { plots (9) } \\
\text { mesomediterranean } \\
\text { zone }\end{array}$ \\
\hline & $0-500 \mathrm{~m}$ & $400-800 \mathrm{~m}$ & $800-1000 \mathrm{~m}$ \\
\hline Species richness & 21.75 & 24.1 & 20.8 \\
\hline Standard deviation & 5.5 & 6.8 & 3.4 \\
\hline Equitability & 0.73 & 0.79 & 0.84 \\
\hline Shannon-Wiener's index & 2.3 & 2.5 & 2.6 \\
\hline
\end{tabular}


Our assumption of plant community differentiation along a gradient of environmental conditions ranging from the coast to inland areas, highlighted by the floristic diversity, is better supported when some concrete environmental variables are introduced and a canonical component analysis (CCA) is conducted. The result of the CCA shows a main gradient of distance of the sea and altitude on axis 1 and a secondary gradient of slope on axis 2 (Fig. 4). The CCA clearly separates on axis 1 (on the left) the strictly coastal plant communities belonging to the thermo-Mediterranean lower bioclimatic range, which prefer thermo-xe-

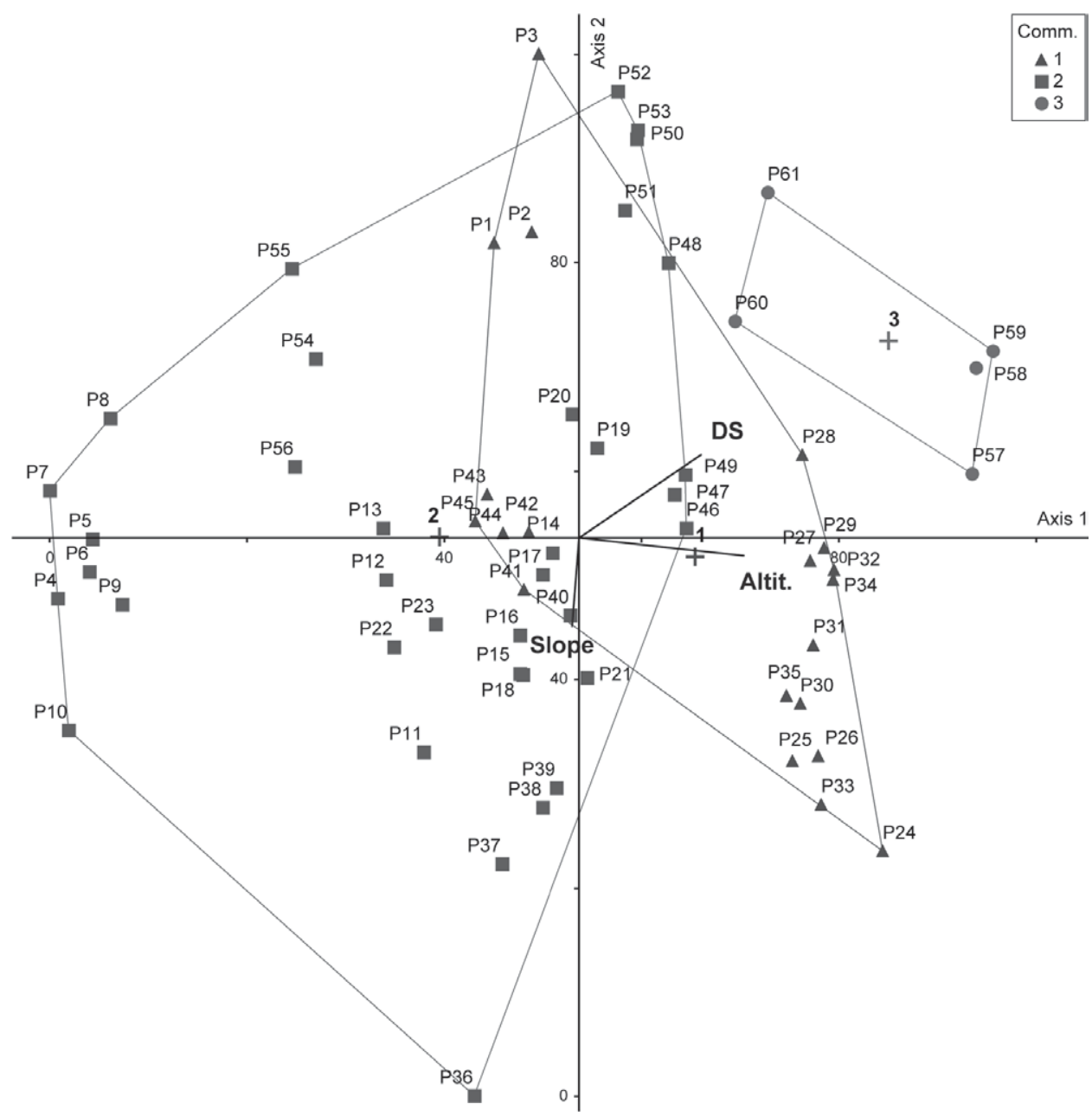

Fig. 4. Canonical correspondence analysis (CCA) plot. Total variance (»inertia«) in the species data: 2.0486; Eigenvalues: axis $1=0.272$; axis $2=0.087$. Plant communities (Comm.): $1-$ Erucastretum virgati centauretosum tauromenitanae facies with Silene fruticosa (polygon marked by triangles and centroid 1); 2 -Erucastretum virgati centauretosum tauromenitanae facies with Lomelosia cretica (polygon marked by squares and centroid 2); 3 -Erucastretum virgati dianthetosum siculi (polygon marked by dots and centroid 3). Main gradient: distance from the sea (DS), altitude (Altit.) and slope of terrain. P1-61 indicates the plots (relevés). 
rophilous conditions, as demonstrated by the presence and dominance of Lomelosia cretica and Dianthus rupicola subsp. rupicola; in the central part are plant communities belonging to the thermo-Mediterranean upper bioclimatic range that prefer thermophilous conditions, as demonstrated by the presence and dominance of Silene fruticosa, Athamanta sicula and Colymbada tauromenitana, while on the right there are the mesophilous plant communities belonging to the meso-Mediterranean bioclimatic range, as demonstrated by the dominance of Dianthus siculus, Ballota hispanica and Odontites bocconei. On axis 2, which correlate with slope, from the bottom up we can observe a reduction of the inclination which reflects a lower number of chasmophilous species.

The Spearman correlation shows a significant correlation between species richness and elevation $(\mathrm{r}=0.62 ; \mathrm{p}<0.05)$, but a low correlation with distance from the sea $(\mathrm{r}=0.35)$. Moreover, the species richness was significantly correlated with temperature $(\mathrm{r}=-0.52 ; \mathrm{p}<$ $0.05)$ and rainfall $(\mathrm{r}=0.67)$. An important correlation was also observed between $C$. tauromenitana density and rainfall $(\mathrm{r}=0.67 ; \mathrm{p}<0.05)$, as well as between $C$. tauromenitana density and species richness $(\mathrm{r}=0.66 ; \mathrm{p}<0.05)$, whereas a low correlation with sea distance $(\mathrm{r}=0.23 ; \mathrm{p}<0.05)$.

\section{Discussion}

Our results indicate that altitude is the main factor influencing both species richness and vegetation composition. This important ecological factor significantly affects also the life forms of the species in response to the hydrothermic gradient linked with altitude (MAHDAVI et al. 2013). The results shows that the lower zones (0-500 $\mathrm{m}$ a.s.1.) are characterized by the predominance of chamaephytes (37\%), while in the thermo-Mediterranean upper zone (500$800 \mathrm{~m}$ a.s.1.) we find a high rate of hemicryptophytes (41\%). Probably the predominance of chamaephytic life form in lower zones suggests a particular adaptation to marine conditions (mainly represented by coastal moisture and marine aerosols). In the meso-Mediterranean belt (800-1000 $\mathrm{m}$ a.s.1.), due to cold winds, once more the chamaephytic life form predominates $(36 \%)$ mixed with hemicryptophytes $(32 \%)$. The results show no significant differences in floristic elements in relation to the three areas identified. In fact from a chorological viewpoint, in these three zones, the floristic element is represented mainly by species with a wide Mediterranean distribution (about 70\%), while the endemic element rate is quite constant.

Therefore, in accordance with ODLAND (2009), we can consider the altitudinal gradient a complex environmental gradient associated with variation in several environmental parameters (slope, rocky type, and distance from sea). The moderate diversity and density of the vegetation in the lower zone (lower thermo-Mediterranean belt) may be related to the severe environmental conditions, that on the one hand limit the growth and productivity of some species, and yet on the other can favor the development of a few highly competitive and specialized species, such as Dianthus rupicola subsp. rupicola, Lomelosia cretica, Limbarda crithmoides, etc. Another serious problem regarding the lower zones is linked to the presence of invasive species such as Opuntia ficus-indica (Fig. 2), that, facilitated by man, has colonized the cliffs there at the expense of the natural populations of $C$. tauromenitana. However, high temperature, low precipitation, high evaporation and high salinity are the main environmental constraints that plants face in the lower zone. These ecophysiological stress factors (especially high temperature and low rainfall) explain the moderate species richness at low altitudes. The high diversity and density in the upper zones may largely be 
related to the high precipitation and moderate temperature that favor the development of many moderately competitive species, such as Dianthus siculus, Odontites bocconei, Colymbada tauromenitana, Silene fruticosa, Athamanta sicula etc.

The extent of the cliffs is another factor that may affect the plant diversity, in particular through habitat heterogeneity and resource availability (ROMDAL and GRYTNES 2007). It is generally expected that in a larger area there is higher habitat heterogeneity and a better chance that larger populations of the species may survive. Most likely, this very significant number of individuals is linked to the large surface area of the rock walls, optimum climatic conditions, the highest degree of naturalness and especially the reduced possibility of anthropogenic habitat destruction. Indeed, the cliffs of M. Veneretta, the largest in the study area, have a high species richness (26) and Shannon-Wiener diversity index (2.57) and probably represent the speciation area of Colymbada tauromenitana and its upper altitudinal limit in the Peloritani district. Therefore, we found that the presence of $C$. tauromenitana was strongly correlated to total species richness and especially hot-humid climatic conditions (Arena et al. 1975, KaLlimanis et al. 2010).

C. tauromenitana grows mainly on limestone outcrops at altitudes between 20 and 800 $\mathrm{m}$, with several other endemic species. It is a characteristic species of the association Erucastretum virgati centauretosum tauromenitanae. The primary habitat of this species is mainly the vertical cliff listed as "Calcareous rocky slopes with chasmophytic vegetation « (COD. 8210, European Community 1992). Moreover, in the study area, this species also grows on rocky slopes (secondary habitat) together with semi-rupicolous low shrub of two different communities: Euphorbietum dendroidis at low altitudes and Micromerio consentinae-Phlomidetum fruticosae at higher altitudes (SCIANDRELlo et al. 2013b), listed as »Thermo-Mediterranean and pre-desert scrub (COD. 5330, European COMMUNity 1992). Considering that dissemination of the some species is favored by the wind and the proximity of a suitable habitat (such as M. Galfa), we might deduce that the altitudinal limit of C. tauromenitana (about $800 \mathrm{~m}$ ) is probably related to the difficulty of the seeds germinating at low temperatures $\left(13^{\circ} \mathrm{C}\right)$ and high rainfall $(1,200 \mathrm{~m})$. As concerns the seed dispersal strategy of the rupicolous species of the study area, the strategy of short distance is the most represented on cliffs. The seeds simply fall from the mother plant or are dispersed by swaying movements of the infructescence or by rain drops hitting the capsules. Other possible ways of seed dispersal on cliffs are exozoochory or anemochory over short distances. From a phytosociological point of view, the classification of relevés (On-line Supplement Tabs. 1-3), using cluster analysis and CCA (Figs. 3, 4), displayed three clear vegetation groups, each with typical species that are useful in characterizing the communities. Choosing just one indicator or guiding species for each community, the first is characterized by the presence of Dianthus rupicola Biv. subsp. rupicola and Lomelosia cretica (L.) Greuter et Burdet (indicating a specific altitude range between 0-500 m), the second by the presence of Silene fruticosa and Colymbada tauromenitana (indicating a specific altitude range between 400 $800 \mathrm{~m}$ ), and in the third the presence of Dianthus siculus C. Presl in J. et C. Presl and Odontites bocconei (Guss.) Walp. subsp. bocconei (indicating a specific altitude range between $800-1,000 \mathrm{~m}$ ) is significant. Therefore, in relation to the floristic composition differences related to altitude, the populations referred to Erucastretum virgati (BRULLO and MARCENÒ 1979) can be divided into three facies, here proposed as:

1. Erucastretum virgati Brullo et Marcenò 1979 centauretosum tauromenitanae Pirola ex Brullo et Marcenò 1979, facies with Lomelosia cretica: Cluster A2 (0-400 m altitude) 
within the thermo-Mediterranean lower belt. This facies is characterized by the dominance of Dianthus rupicola subsp. rupicola and Lomelosia cretica, together with other thermorupicolous species of the Dianthion rupicolae alliance, such as Antirrhinum siculum, Brassica incana, Colymbada tauromenitana ect. and other several thermo-xerophilous species of the Oleo-Ceratonion alliance, such as Euphorbia dendroides, Phlomis fruticosa, Olea europaea var. sylvestris, Prasium majus, Teucrium fruticans, Ruta chalepensis, ect. (On-line Supplement Tab. 2).

2. Erucastretum virgati Brullo et Marcenò 1979 centauretosum tauromenitanae Pirola ex Brullo et Marcenò 1979, facies with Silene fruticosa: Cluster A1 (400-800 m altitude) within the thermo-Mediterranean upper belt. This facies is characterized by the dominance of Silene fruticosa and Colymbada tauromenitana, together with Hypochoeris laevigata, Athamanta sicula, Ballota hispanica, Teucrium flavum, ect., and some thermo-mesophilous species, such as Bupleurum fruticosum, Emerus major subsp. emeroides, Fraxinus ornus, Pistacia terebinthus, Quercus ilex, ect. (On-line Supplement Tab. 1).

3. Erucastretum virgati Brullo et Marcenò 1979 dianthetosum siculi subass. nova, Characteristics species: Dianthus siculus and Odontites bocconei subsp. bocconei, Holotypus: relevé 61, Cluster B (800-1,000 m altitude) within the meso-Mediterranean belt. This facies is characterized by the dominance of Dianthus siculus and Odontites bocconei subsp. bocconei, together with other rupicolous species of the Asplenietalia glandulosi order, such as Silene fruticosa, Brassica incana, Anthyllis vulneraria subsp. busambarensis, Teucrium flavum, Athamanta sicula, Hypochoeris laevigata, Ballota hispanica, Sedum dasyphyllum, ect. (On-line Supplement Tab. 3).

The limestone cliffs are populated by chasmophilous vegetation ascribed to Erucastretum virgati, widespread in the southern sector of the Calabria and eastern part of Sicily with several subassociations geographically well delimited, highlighting the geology and paleogeography connections of the Calabrian Peloritani Arc (BRullo et al. 1998b, Brullo et al. 2001).

Overall, endemic species play a central role in biodiversity conservation, because of the habitat loss and climate change, due to their often small population sizes, low genetic diversity and specific habitat requirements (GARGANO et al. 2007, BRULLO et al. 2011, TRIGAS et al. 2012, Brullo et al. 2013, VAndePitTe et al. 2013). In line with the objectives of the Habitats Directive, their preservation therefore becomes a priority (MÉDAIL and QuÉzel 1999, MYERS et al. 2000). In southern Italy the cliffs preserve endemic species of very high phytogeographical and ecological value, used also to characterize well-defined territorial units (BRULlo et al. 1998b, Wagensommer and di Pietro 2007, di Pietro and Wagensommer 2008, Terzi and D’Amico 2008, Minissale et al. 2013).

\section{Conclusion}

In conclusion, the priority conservation measures proposed, based on field observations, for the rupicolous species are: (1) protection of the rupicolous habitat with a high number of endemic species; (2) creation of plant micro-reserves (PMR) or sites of community importance (SCI); (3) planning and land management (regulation of human activities, limitation of fire, eradication of alien species such as Opuntia ficus-indica on the cliffs); (4) restoration of damaged habitats; (5) collection of local germplasm for ex situ conservation; (6) promoting the integration of some threatened endemic species (in situ/ex situ); (7) a regional law on 
the conservation of endemic species and (8) genetic analysis of the $C$. tauromenitana populations to understand their future maintenance. Furthermore, in order to preserve the native rupicolous species, it is also necessary to plan targeted interventions for removal of invasive species and the prohibition on cultivating these species in neighboring areas.

\section{Acknowledgements}

We are grateful to Prof. P. Minissale for useful comments and to the two anonymous reviewers for further improving the manuscript with their suggestions.

\section{References}

Arena, M., Gramuglio, G., Villari, R., 1975: Anatomical and ecological observations on Centaurea tauromenitana Guss. Atti della Società peloritana di scienze fisiche, matematiche e naturali 21, 99-104.

Braun-Blanquet, J., 1964: Pflanzensoziologie. Grundzüge der Vegetationskunde. 3. Auff. Springer, Wien, New York.

Brullo, C., Brullo, S., Giusso del Galdo, G., Minissale, P., Sciandrello, S., 2011: Astragalus raphaelis $\mathrm{G}$. Ferro (Fabaceae), critical species from Sicily and taxonomic remarks on A. sect. Sesamei DC. Nordic Journal of Botany 29, 518-533.

Brullo, C., Brullo, S., Giusso del Galdo, G., Minissale, P., Sciandrello, S., 2013: Astragalus kamarinensis (Fabaceae), a new species from Sicily. Annales Botanici Fennici 50, 61-67.

Brullo, C., Minissale, P., Sciandrello, S., Spampinato, G., 2011: Phytogeographic survey on the endemic vascular fora of the Hyblaean territory (SE Sicily, Italy). Acta Botanica Gallica 158, 617-631.

Brullo, S., Grillo, M., Guglielmo, A., 1998a. Considerazioni fitogeografiche sulla flora iblea. Bollettino Accademia Gioenia di Scienze Naturali Catania 29, 45-111.

Brullo, S., Marcenò, C., 1979: Dianthion rupicolae nouvelle alliance sudtyrrhenienne des Asplenietalia glandulosi. Documents Phytosociologiques 4, 131-146.

Brullo, S., Marcenò, C., Siracusa, G., 1998b: La classe Asplenietea trichomanis in Sicilia. Colloques Phytosociologiques 23, 467-538.

Brullo, S., Minissale, P., Giusso del Galdo, G., Siracusa, G., Spampinato, G., 2002: Considerazioni sintassonomiche e fitogeografiche sulla vegetazione della Sicilia. Bollettino Accademia Gioenia di Scienze Naturali Catania 35, 325-359.

Brullo, S., Minissale, P., Spampinato, G., 1995: Considerazioni fitogeografiche sulla flora della Sicilia. Ecologia Mediterranea 21, 99-117.

Brullo, S., Scelsi, S., Spampinato, G., 2001: La vegetazione dell'Aspromonte, studio fitosociologico. Ed. Baruffa, Reggio Calabria.

Brullo, S., Scelsi, F., Siracusa, G., Spampinato, G., 1996: Caratteristiche bioclimatiche della Sicilia. Giornale Botanico Italiano 130, 177-185.

Carmel, Y., Flather, C. H., 2004: Comparing landscape scale vegetation dynamics following recent disturbance in climatically similar sites in California and the Mediterranean basin. Landscape Ecology 19, 573-590. 
Conti, F., Abbate, G., Alessandrini, A., Blasi, C., (eds.) 2005: An annotated checklist of the Italian vascular flora. Palombi, Roma.

Conti, F., Manzi, A., Pedrotti, F., 1997: Liste rosse Regionali delle Piante d'Italia. WWFSBI, Camerino.

Cowling, R. M., Rundel, P. W., Lamont, B. B., Arroyo, M. K., Arianoutsou, M., 1996: Plant diversity in Mediterranean-climate regions. Trends in Ecology and Evolution 11, $362-366$.

Davis, P. H., 1951: Cliff vegetation in the Eastern Mediterranean. Journal of Ecology 39, 63-93.

de Santis, C., Pavone, P., Zizza, A., 1976: Numeri cromosomici per la flora italiana: 232237. Informatore Botanico Italiano 8, 74-81.

di Pietro, R., Wagensommer, R. P., 2008. Analisi fitosociologica su alcune specie rare e/o minacciate del Parco Nazionale del Gargano (Italia centro-meridionale) e considerazioni sintassonomiche sulle comunità casmofitiche della Puglia. Fitosociologia 45, $177-$ 200.

European Community, 1992. European Community Directive 92/43/EEC on the conservation of natural habitats and of wild fauna and flora (Habitat Directive). European Community, Brussels.

Fiori, A., 1923-29: Nuova flora analitica d'Italia. Firenze.

Gargano, D., Fenu, G., Medagli, P., Sciandrello, S., Bernardo, L., 2007: The status of Sarcopoterium spinosum (Rosaceae) at the western periphery of its range: Ecological constraints lead to conservation concerns. Israel Journal of Plant Sciences 55, 1-13.

Giardina, G., Raimondo, F. M., Spadaro, V., 2007: A catalogue of plants growing in Sicily. Bocconea 20, 5-582.

Gramuglio, G., 1967: Nuovo areale di Centaurea tauromenitana Guss. endemica dei Peloritani.; Atti della Società peloritana di scienze fisiche, matematiche e naturali 13, 153-156.

Gramuglio, G., Triscari, C., Arena, M., 1985: Ancora una nuova stazione di Centaurea tauromenitana Guss., endemica dei Monti Peloritani (Sicilia Nord-Orientale). Informatore Botanico Italiano 15, 163-167.

Gussone, J., 1827: Florae Siculae Prodromus sive plantarum in Sicilia ulteriori nascentium enumeratio secundum systema linneanum disposita 1 . Neapoli.

IuCN, 2001: IUCN Red List Categories and Criteria, 3.1. IUCN Species Survival Commission. IUCN. Gland, Cambridge.

IuCN, 2008: Guidelines for using the IUCN Red List categories and criteria, 7.0. Standards and Petitions Working Group of the IUCN Species Survival Commission Biodiversity Assessments Sub-Committee.

Kallimanis, A. S., Bergmeier, E., Panitsa, M., Georghiou, K., Delipetrou, P., Dimopoulos, P., 2010: Biogeographical determinants for total and endemic species richness in a continental archipelago. Biodiversity and Conservation 19, 1225-1235.

Lentini, F., Catalano, S., Carbone, S., 2000: Carta geologica della Provincia di Messina. Scala 1:50.000. S.E.L.C.A. Firenze.

Lojacono Pojero, M., 1908: Flora sicula, o descrizione delle piante vascolari spontanee o indigenate in Sicilia. 3, 93, Palermo. 
Mahdavi, P., Akhani, H., van der Maarel, E., 2013: Species diversity and life-form patterns in steppe vegetation along a $3000 \mathrm{~m}$ altitudinal gradient in the Alborz Mountains, Iran. Folia Geobotanica 48, 7-22.

Médail, F., Verlaque, R., 1997: Ecological characteristics and rarity of endemic plants from Southeast France and Corsica: implications for biodiversity conservation. Biological Conservation 80, 269-281.

MÉDAIL, F., QuÉzEL, P. 1999: Biodiversity hotspots in the Mediterranean basin: setting global conservation priorities. Conservation Biology 13, 1510-1513.

Myers, N., Mittermeier, R. A., Mittermeier, C. G., Da Fonseca, G. A. B., Kents, J., 2000: Biodiversity hotspots for conservation priorities. Nature 403, 853-858.

Minissale, P., Brullo, C., Brullo, S., Giusso del Galdo, G., Sciandrello, S., 2013: Bituminaria basaltica (Fabaceae), a new species from Mediterranean area. Phytotaxa 98 (1), 1-15.

Minissale, P., Sciandrello, S., 2013: A relict wood of Juniperus turbinata Guss. (Cupressaceae) in Sicily. Ecological features and conservation perspectives. Plant Biosystems 147 (1), 145-157.

Odland, A., 2009: Interpretation of altitudinal gradient in south Central Norway based on vascular plants as environmental indicators. Ecological Indicators 9, 409-421.

Pignatti, S., 1982: Flora d'Italia (1-3). Edagricole. Bologna.

Pirola, A., 1961: L'Associazione a Scabiosa cretica a Taormina (Sicilia orientale). Archivio Botanico Italiano 37, 132-144.

Pisanu, S., Mameli, G., Farris, E., Filigheddu, R., 2011: A natural homoploid hybrid between Centaurea horrida and Centaurea filiformis (Asteraceae) as revealed by morphological and genetic traits. Folia Geobotanica 46, 69-86

PoDANI, J., 2001: SYN-TAX 2000, computer program for multivariate analysis in ecology and taxonomy. Scientia Publishing, Budapest.

Raimondo, F. M., Spadaro, V., 2009: Addenda et emendanda to the »A catalogue of plants growing in Sicily«. Flora Mediterranea 19, 303-312.

Rivas Martinez, S., 1993: Bases para una nueva clasification bioclimatica de la tierra. Folia Botanica Matritensis 10, 1-23.

Rivas-Martinez, S., 2004: Bioclimatic map of Europe: Bioclimates, scale 1:16 millions. Cartographic Service, University of Leon.

Romdal, T. S., Grytnes, J. A., 2007: An indirect area effect on elevational species richness patterns. Ecography 30, 440-448.

Rossi, G., Gentili, R., 2008: A partnership project for a new Red List of the Italian flora. Plant Biosystems 142, 302-304.

Schröter, D., Cramer, W., Leemans, R., Prentice, I. C., Araújo, M. B., Arnell, N. W., Bondeau, A., Bugmann, H., Carter, T. R., Gracia, C. A. et al., 2005: Ecosystem service supply and vulnerabilità to global change in Europe. Science 310, 1333-1337.

Sciandrello, S., Brullo, C., Brullo, S., Giusso del Galdo, G., Minissale, P., Salmeri, C., 2013a: A new species of Brassica sect. brassica (Brassicaceae) from Sicily. Plant Biosystems $147,812-820$. 
Sciandrello, S., D’Agostino, S., Minissale, P., 2013b: Vegetation analysis of the Taormina region in Sicily: a plant landscape characterized by geomorphology variability and both ancient and recent anthropogenic influences. Lazaroa 34, 151-190.

Terzi, M., D'Amico, F. S., 2008: Chasmophytic vegetation of the class Asplenietea trichomanis in south-eastern Italy. Acta Botanica Croatica 67 (2), 147-174.

Thompson, J. D., 2005: Plant evolution in the Mediterranean. Oxford University Press, Oxford.

Tomaselli, V., Tenerelli, P., Sciandrello, S., 2012: Mapping and quantifying habitat fragmentation in small coastal areas: a case study of three protected wetlands in Apulia (Italy). Environmental Monitoring and Assessment 184, 693-713.

Trigas, P., Tsiftsis, S., Tsiripidis, I., IATrou, G., 2012: Distribution patterns and conservation perspectives of the endemic flora of Peloponnese (Greece). Folia Geobotanica 47, 421-439.

Tutin, T. G., et al. 1964-80: Flora Europaea (1-5). Univ. Press, Cambridge.

Vandepitte, K., Gristina, A. S., De Raedt, R., Roldán-Ruiz, I., Marcenò, C., Sciandrello, S., Honnay, O., 2013: Conservation genetics of an endemic from the Mediterranean Basin: high genetic differentiation but no genetic diversity loss from the last populations of the Sicilian Grape Hyacinth Leopoldia gussonei. Conservation Genetics 14: 963-972.

VAN DER MAARel, E., 1979: Transformation of cover-abundance values in phytosociology and its effects on community similarity. Vegetatio 39, 97-114.

Wagensommer, R. P., Di Pietro, R., 2007: Aspetti cenologici e sintassonomici di alcune specie rare e/o minacciate del Gargano (Puglia settentrionale). Fitosociologia 44(2) suppl. 1, 231-234.

Westhoff, V., van der MaArel, E., 1978: The Braun-Blanquet approach. In: Whittaker, R H. (ed.), Classification of plant communities, second ed. Dr Junk, The Hague, The Netherlands, pp. 287-399. 